\title{
DESENROLANDO BARTHES E OUTRAS SEMIOLOGIAS
}

Renato Negrão* (2012), de Renato Negrão. Ele traz dois performers escrevendo uma frase de Barthes, no chão, utilizando rolos de barbante. Essa uma frase de Barthes, no chão, utilizando rolos de barbante. Essa cena instigante foi propulsora para alinhavarmos outras três tecituras desse livro para conviverem ainda mais com Roland Bathes.

O poema seguinte, sem titulo, tema muito caro ao pensamento barthesiano, as justaposições dos discursos - "magela une cinema e performance nas ciências aquosas".

"Coreografia", o terceiro poema (instalação), reúne outras semiologias ao exibir mapas afetivos de textos urbanos e o "pensamento disparado milton santos", além de outros espaços coreográficos.

Fechando a série, o jogador Dadá Maravilha e seus gols são lembrados em "Dadá", poema que também integra a instalação poética do museu de futebol do Mineirão. Esse texto foi composto a partir de uma entrevista dada pelo ídolo do Atlético Mineiro.
* Poeta, compositor, artista visual e professor, nascido em Belo Horizonte em 1968. Autor dos livros No calo (1996), Dragões do paraíso (1997), reunidos e republicados em Os dois primeiros um lote vago (Selo Editorial, 2004) e Vicente viciado (Rótula 2012). oficine 


\section{DESENROLANDO BARTHES}

no início era o referente e o verbo

e o processo incessante

de produção de sentido

a isso se deu o nome de semiose

cadeia - ou galeria -

infinita e incessante

do discurso e da cultura

labuta poética sobre o sentido

de se produzir sentido sobre as coisas

dois performers escrevem no chão

- utilizando rolos de barbante -

uma mesma frase do semiólogo roland barthes

a frase escrita é modificada ou subvertida por meio de fluxos de pensamento e/ou ocorrências sonoras

- conversas onomatopeias -

vivenciadas no local

logo duas frases diferentes surgem

no espaço expositivo

as linhas são ligadas a pessoas da audiência e em seguida deslocadas pelo chão da galeria em direção à rua até o término do barbante o que a audiência fará com as linhas que os ligam? haverá tempo para que a audiência

leia a frase escrita no chão?

a que fim levará o fim da linha?

julieta de souza faz filosofia pelo suporte música astolfo andrade mostra escultura análoga ao teatro epaminondas cerqueira diz cinema com a mão da literatura mestra elza joga capoeira no suporte do desing tiago josé define a curadoria ao manejar parangolé carlos martins sujeita tela e teclado para produzir tipos roberta encontra na moda a forma da instalação em marcos ubaldo arte gourmet e astronomia uma coisa só martina transpõe o bordado para a dança

denise transforma romances em ready-mades dayse liga lógica e dadá no mamulengo

magela une cinema e performance nas ciências aquosas kátia suzy realiza poesia pela autoajuda

jean cardoso faz autoajuda na plataforma da poesia

jorge ramos pensando fazer poesia faz história

clara arantes faz poesia para afugentar o tédio
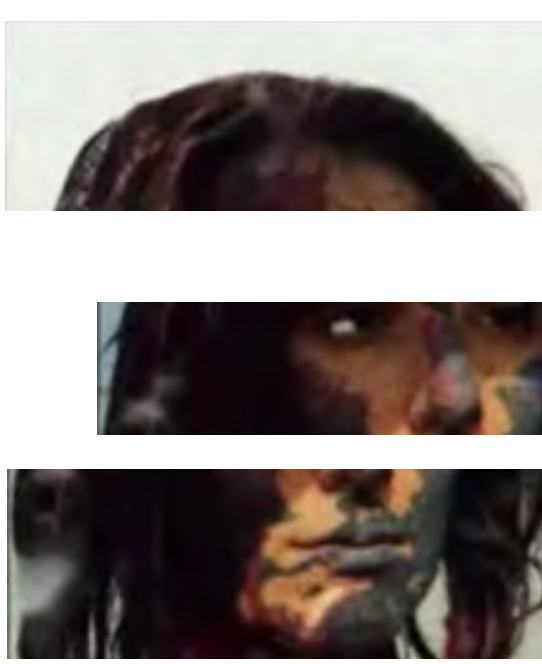

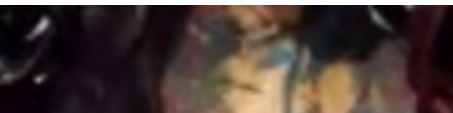

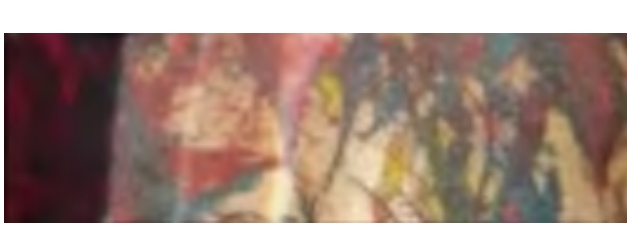




\section{COREOGRAFIA}

o espaço coreográfico da palavra e sua aplicabilidade semântica

são pensados como estímulo

a outras configurações corporais

nossos corpos merecem e podem dar respostas mais criativas

aos textos urbanos para além

de suas palavras de ordem

e de consumo

gesto como construção

transitoriedade como eixo

dispersão como método

1. MAPA AFETIVO DOS TEXTOS URBANOS deslocar por um percurso urbano cuja cartografia se dê por um viés afetivo estabelecer um relacionamento gestual poético sensualizado

com um ou mais textos urbanos que encontrar

\section{PELE}

seus sons, seus átomos suas células

seus órgãos internos sua pele

sua roupa sua casa sua cidade

seu mundo

como camadas da sua epiderme

3. PENSAMENTO DISPARADO MILTON SANTOS

o mundo como um conjunto

de possibilidades não apenas

um conjunto de realidades e sua convicção

de que outros mundos poderiam ser criados

a partir dos mesmos materiais

4. DANÇA

crie na cidade

- a partir da seleção de palavras

encontradas por intermédio do seu desenho

da materialidade gráfica

dos contornos espaciais dessas palavras

e da dimensão poética e sensualizada

dos seus significados -

outros estímulos corporais

abrindo no horizonte

novas perspectivas

com os textos urbanos 
DADÁ

- futebol é o seguinte

chegou ali e tem tranquilidade

é só aplicar o sutil o mirabolante

a raiz quadrada o labirinto

que não tem jeito pro goleiro não

é cair e levantar para buscar

o caroço lá dentro

- que negócio é esse de sutil

mirabolante e raiz quadrada

- não posso dize

é segredo profissional

outro dia criei mais um gol

o independência

- poesia é o seguinte

chegou ali e tem tranquilidade

é só aplicar o sutil o mirabolante

a raiz quadrada o labirinto

que não tem jeito pro leitor não

é cair e levantar para buscar

o caroço lá dentro

- que negócio é esse de sutil

mirabolante e raiz quadrada
- não posso dizer

é segredo profissional

outro dia criei mais um poema

o independência

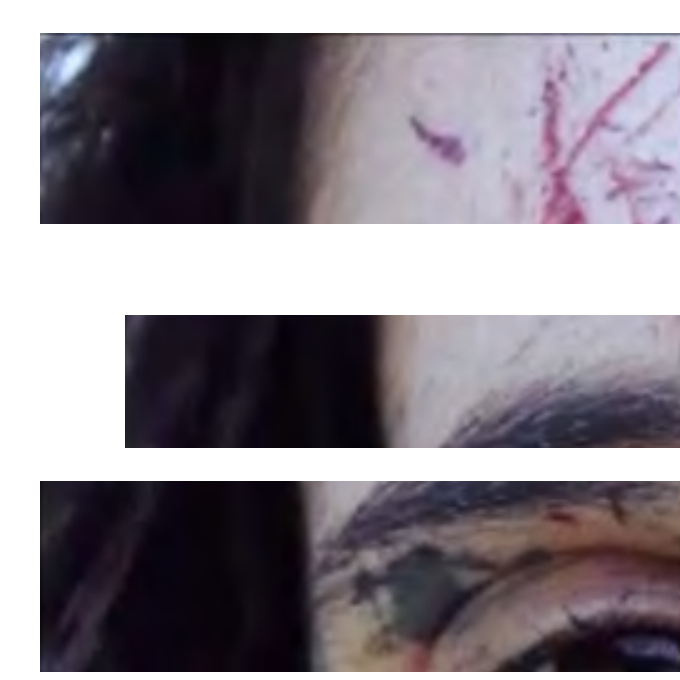

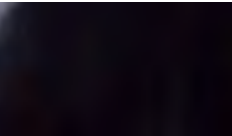

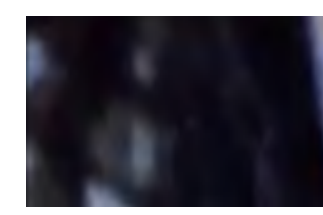

